\title{
Article
}

\section{Ethylenediaminetetraacetic Acid Disodium Salt Acts as an Antifungal Candidate Molecule against Fusarium graminearum by Inhibiting DON Biosynthesis and Chitin Synthase Activity}

\author{
Xiu-Shi Song ${ }^{1,2}{ }^{\mathbb{D}}$, Kai-Xin Gu ${ }^{1}$, Jing Gao ${ }^{1}$, Jian-Xin Wang ${ }^{1}$, Shao-Chen Ding ${ }^{1}$ and Mingguo Zhou ${ }^{1,2, *}$ \\ 1 Key Laboratory of Pesticides, College of Plant Protection, Nanjing Agricultural University, \\ Nanjing 210095, China; songxs@njau.edu.cn (X.-S.S.); xinkaigu@126.com (K.-X.G.); gjing5898@163.com (J.G.); \\ jianxin-wang@njau.edu.cn (J.-X.W.); shaochend@126.com (S.-C.D.) \\ 2 The Key Laboratory of Plant Immunity, Nanjing Agricultural University, Nanjing 210095, China \\ * Correspondence: mgzhou@njau.edu.cn; Tel./Fax: +86-025-84395641
}

check for

updates

Citation: Song, X.-S.; Gu, K.-X.; Gao, J.; Wang, J.-X.; Ding, S.-C.; Zhou, M. Ethylenediaminetetraacetic Acid Disodium Salt Acts as an Antifungal Candidate Molecule against Fusarium graminearum by Inhibiting DON Biosynthesis and Chitin Synthase Activity. Toxins 2021, 13, 17 .

https://doi.org/10.3390/toxins13010 017

Received: 24 November 2020 Accepted: 24 December 2020 Published: 27 December 2020

Publisher's Note: MDPI stays neutral with regard to jurisdictional claims in published maps and institutional affiliations.

Copyright: () 2020 by the authors. Licensee MDPI, Basel, Switzerland. This article is an open access article distributed under the terms and conditions of the Creative Commons Attribution (CC BY) license (https: / / creativecommons.org/ licenses/by/4.0/).

\begin{abstract}
Fusarium fungi are the cause of an array of devastating diseases affecting yield losses and accumulating mycotoxins. Fungicides can be exploited against Fusarium and deoxynivalenol (DON) production. However, Fusarium resistance to common chemicals has become a therapeutic challenge worldwide, which indicates that new control agents carrying different mechanisms of action are desperately needed. Here, we found that a nonantibiotic drug, ethylenediaminetetraacetic acid disodium salt (EDTANa 2 ), exhibited various antifungal activities against Fusarium species and DON biosynthesis. The infection of wheat seeding caused by F. graminearum was suppressed over $90 \%$ at $4 \mathrm{mM} \mathrm{EDTANa}_{2}$. A similar control effect was observed in field tests. Mycotoxin production assays showed DON production was significantly inhibited, $47 \%$ lower than the control, by $0.4 \mathrm{mM}$ EDTANa 2 . In vitro experiments revealed a timely inhibition of $\mathrm{H}_{2} \mathrm{O}_{2}$ production as quickly as $4 \mathrm{~h}$ after amending cultures with EDTANa $\mathrm{E}_{2}$ and the expression of several TRI genes significantly decreased. Chitin synthases of Fusarium were $\mathrm{Mn}^{2+}$-containing enzymes that were strongly inhibited by $\mathrm{Mn}^{2+}$ deficiency. EDTANa $a_{2}$ inhibited chitin synthesis and destroyed the cell wall and cytomembrane integrity of Fusarium, mainly via the chelation of $\mathrm{Mn}^{2+}$ by EDTANa 2 , and thus led to Mn deficiency in Fusarium cells. Taken together, these findings uncover the potential of EDTANa 2 as a fungicide candidate to manage Fusarium head blight (FHB) and DON in agricultural production.
\end{abstract}

Keywords: Fusarium; EDTANa 2 ; deoxynivalenol; chitin synthases; manganese ion

Key Contribution: EDTANa 2 is identified as a fungicide candidate molecule to control the growth and DON production of Fusarium graminearum. The antifungal activity of EDTANa 2 mainly results from $\mathrm{Mn}$ deficiency in cells.

\section{Introduction}

Fusarium is a globally important genus of fungal pathogens, responsible for many devastating diseases of plants and various serious diseases of humans [1,2]. Fusarium species are widely present in soil, plants and other organic substrates and have widespread distributions [3]. Species such as Fusarium graminearum, Fusarium oxysporum and Fusarium verticillioides can infect many crop plants, vegetables and flowers [2,4-8]. One of the major diseases caused by Fusarium is Fusarium head blight (FHB), which is becoming more and more serious recently and causing concern. FHB results in yield loss and damaging of cereal grains [9,10]. Additionally, Fusarium spp. produce various types of mycotoxins, including deoxynivalenol (DON) and acetyl-deoxy-nivalenol (3-ADON and 15-ADON), that suppress humoral and cellular immunity and are thus highly detrimental to human and animal health [11,12]. DON is a mycotoxin virulence factor that promotes growth of the F. graminearum fungus in wheat floral tissues [13]. 
Practices used to control FHB and DON include rotation with nonhost crops and tillage [14], planting of resistant cultivars [15], and application of fungicides [16]. Essentially, current protective measures against Fusarium species mainly rely on fungicides, such as benzimidazole, triazole, demethylation inhibitor and quinone outside inhibitor. However, some of these can lead to the enhancement of DON biosynthesis in the infected wheat $[17,18]$. Therefore, new molecules are needed to control FHB and inhibit DON biosynthesis.

In addition, Fusarium isolates are susceptible to mutations that lead to phenotypes of tolerance towards common antifungal drugs $[19,20]$. Resistance to fungicides allows pathogens to survive fungicide treatment. The time taken for a new resistant mutant to reach a population size that is unlikely to die out by chance is called "emergence time". Prolonging emergence time would delay loss of control [21]. To date, the drawbacks of both scientific control strategies and the use of effective fungicides need to be addressed $[8,22,23]$. Undoubtedly, the processes of discovery and development of new antifungal drugs in the pharmaceutical industry are not only laborious and time consuming but also costly [24]. This is particularly true, as fungicides with novel modes of action are only rarely found, and resistance to single-target fungicides may occur within few years [25]. Some nonantibiotic drugs were recently reported to exhibit some antimicrobial activity against bacteria and Candida albicans [26,27].

Ethylenediaminetetraacetic acid (EDTA) is a chelating agent targeting divalent cations and has been previously used in oil fields to increase oil production and inhibit scale formation $[28,29]$. EDTA has also been shown to possess antimicrobial activities against bacteria and C. albicans because it can limit the availability of essential cations. The chelation of cations causes a separation of lipopolysaccharides from the outer membrane of microbial cells and thus increases the membrane permeability and subsequently leads to cell death in bacteria [30-35]. Generally considered safe, EDTA has been used intensively in the food and therapeutic industry $[33,36,37]$. Here, we demonstrated that EDTANa 2 had antifungal activity against Fusarium graminearum and DON biosynthesis. Our study contributes to the understanding of the mechanisms underlying EDTANa ${ }_{2}$ control of FHB and provides a fungicide candidate molecule against Fusarium graminearum and its mycotoxin biosynthesis.

\section{Results}

2.1. Ethylenediaminetetraacetic Acid Disodium Salt Exhibits Various Antifungal Activities against Fusarium Species

Mycelial growth was inhibited with $0.15 \mathrm{mM}$ ethylenediaminetetraacetic acid or ethylenediaminetetraacetic acid sodium salt (Figure 1A). The effectiveness of ethylenediaminetetraacetic acid sodium salt was affected by its number of sodium ions. For all tested reagents, EDTANa 2 had the best antifungal activity in terms of growth inhibition as well as cell swelling effects, closely followed by EDTANa 3 . The antifungal activity of EDTANa was similar to that of EDTA. Moreover, the mycelial growth and morphology with the 0.3, $0.45,0.6 \mathrm{mM}$ sodium ion treatments showed no difference from the control group (only the treatment with $0.6 \mathrm{mM}$ sodium ion is shown in Figure 1A), indicating that the sodium ions had no effect on Fusarium growth at a concentration less than $0.6 \mathrm{mM}$.

To test the antifungal activity of EDTANa 2 , thirteen isolates of Fusarium, including $F$. acuminatum, F. asiaticum, F. avenaceum, F. concentricum, F. culmorum, F. equiseti, F. fujikuroi, F. graminearum, F. lateritium, F. oxysporum, F. proliferatum, F. solani and F. verticillioides were inoculated into 96-well microtiter plates. The minimum inhibitory concentrations (MICs) of $\mathrm{EDTANa}_{2}$ on the test pathogens varied from 9.37 to $18.75 \mathrm{mM}$ (Table S1). The lowest MIC value was observed for F. asiaticum, F. avenaceum, F. equiseti, F. fujikuroi and F. proliferatum, while the other Fusarium isolates (except F. lateritium) had MIC values of $18.75 \mathrm{mM}$. The MIC value of EDTANa ${ }_{2}$ to F. lateritium was $200 \mathrm{mM}$. Surprisingly, EDTANa 2 did not show any antifungal activity against $F$. lateritium but promoted its growth in the range of 4.69-150 mM. 


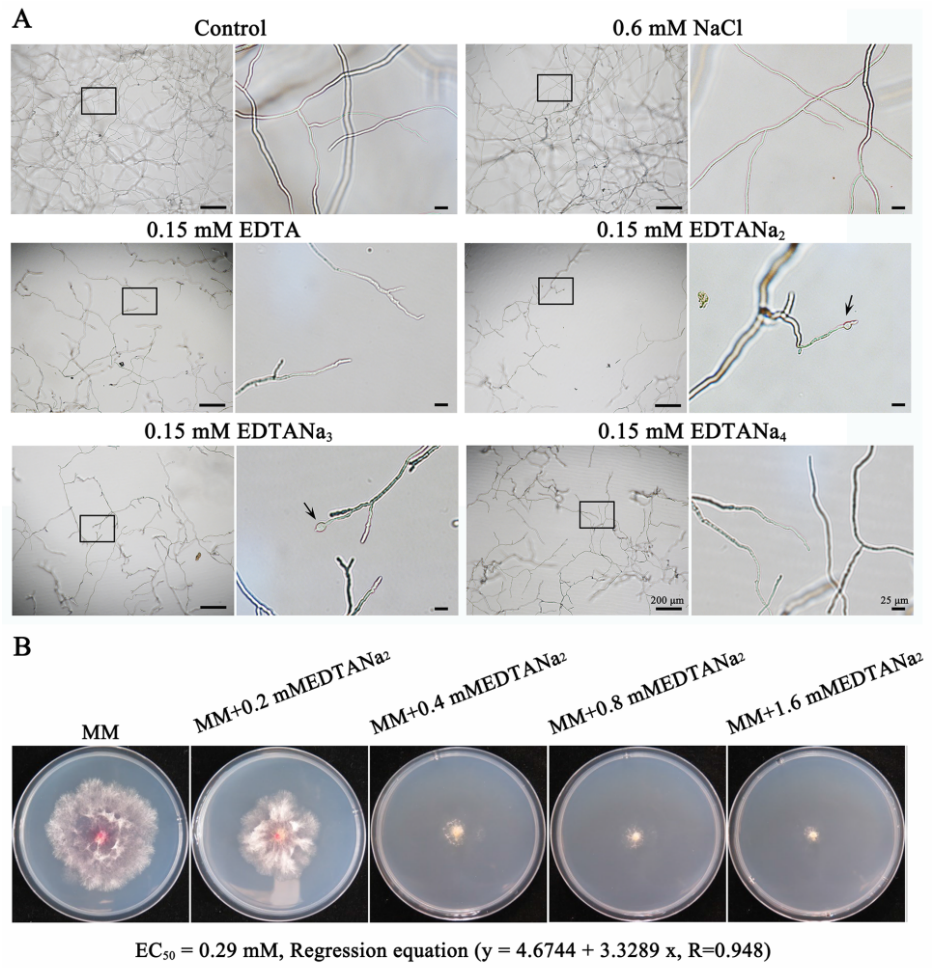

Figure 1. The antifungal activity of ethylenediaminetetraacetic acid disodium salt $(\text { EDTANa })_{(n)}$ against Fusarium graminearum. (A) The influence of sodium ion on EDTA effects. Conidia of $F$. graminearum were grown in SNA $\left(1 \mathrm{~g} \mathrm{~L}^{-1} \mathrm{KH}_{2} \mathrm{PO}_{4}, 1.0 \mathrm{~g} \mathrm{~L}^{-1} \mathrm{KNO}_{3}, 0.5 \mathrm{~g} \mathrm{~L}^{-1} \mathrm{MgSO}_{4} \cdot 7 \mathrm{H}_{2} \mathrm{O}\right.$, $0.5 \mathrm{~g} \mathrm{~L}^{-1} \mathrm{KC} 1,0.2 \mathrm{~g} \mathrm{~L}^{-1}$ glucose, $0.2 \mathrm{~g} \mathrm{~L}^{-1}$ sucrose) medium with $0.15 \mathrm{mM} \mathrm{EDTANa}_{(n)}(n=0,2,3$ or 4; $\mathrm{pH} 4$.2) and were photographed after $24 \mathrm{~h}$ of cultivation. The effect of sodium ions was assayed by replacing $\operatorname{EDTANa}_{(n)}$ with $\mathrm{NaCl}$ and was used as the second control group. Each right panel is an enlarged view of the area in the black box in the left panel. The arrows indicate conglobate structures after $24 \mathrm{~h}$ in response to $\operatorname{EDTANa}_{(n)}$. The experiment was repeated three times with the same patterns. (B) Sensitivities of F. graminearum to EDTANa 2 . The measurement was performed on minimal medium (MM) after $4 \mathrm{~d}$ at $25^{\circ} \mathrm{C}$. Photos were taken 3 days after incubation. The experiment was repeated three times with the same patterns.

For F. graminearum $\mathrm{PH}-1$ strain, a linear regression of the percentage inhibition related to the control of mycelial growth versus the $\log _{10}$ transformation for each of EDTANa 2 concentration was obtained. The median effective concentration $\left(\mathrm{EC}_{50}\right)$ was calculated for each strain using a linear equation. The $\mathrm{EC}_{50}$ value of EDTANa 2 for $F$. graminearum $\mathrm{PH}-1$ strain was $0.29 \mathrm{mM}\left(107.88 \mathrm{mg} \mathrm{L}^{-1}\right)$ (Figure 1B).

\subsection{The Control Effect and Phytotoxicity Test of Ethylenediaminetetraacetic Acid Disodium Salt}

The EDTANa 2 for control of seedling blight in wheat was effective, reducing disease severity by $59 \%, 79 \%, 92 \%$ at $1 \mathrm{mM}, 2 \mathrm{mM}$ and both $4 \mathrm{mM}$ and $8 \mathrm{mM}$, relative to the inoculated control, respectively (Figure 2A). No significant different effect was observed among $1 \mathrm{mM}$ to $8 \mathrm{mM} \mathrm{EDTANa}_{2}$, indicating that the control effect was stable within that range under controlled conditions. To ascertain whether the EDTANa 2 molecule could inhibit Fusarium infection under natural conditions, a crop phytopathogen, F. graminearum, was chosen for pathogenicity assays by spray inoculation experiments. The disease incidences were recorded 21 days post inoculation (dpi). The field experiment was conducted for two years (2018 and 2019) and produced similar results to the previously described experiments. As shown in Figure 2B, EDTANa 2 significantly reduced Fusarium head blight in the field. After spray treatment with $7 \mathrm{~g} \mathrm{ha}^{-1}$ EDTANa $_{2}$, F. graminearum caused $52 \%$ and $45 \%$ spikelets infection at $21 \mathrm{dpi}, 45 \%$ and $49 \%$ reduction compared to the sterile water control in 2018 and 2019, respectively. When the dosage of EDTANa 2 increased to $70 \mathrm{~g} \mathrm{ha}^{-1}$, 
the incidence of disease decreased to $12 \%$ and $8 \%, 87 \%$ and $91 \%$ reduction compared to the sterile water control in 2018 and 2019, respectively. In 2019, the incidence of disease treated with $70 \mathrm{~g} \mathrm{ha}^{-1}$ EDTANa $_{2}$ had a $70 \%$ reduction compared to the $140 \mathrm{~g} \mathrm{ha}^{-1} \mathrm{car}^{-}$ bendazim treatment (Figure 2B). To further analyze the influence of EDTANa ${ }_{2}$ treatments on spikelet morphology, we sprayed a series of EDTANa 2 concentrations $\left(7 \mathrm{~g} \mathrm{ha}^{-1}\right.$ to $4000 \mathrm{~g} \mathrm{ha}^{-1}$ ) onto wheat spikelets, and the results showed that there was little change in spikelets morphology following spray application of $7 \mathrm{~g} \mathrm{ha}^{-1}$ to $1600 \mathrm{~g} \mathrm{ha}^{-1} \mathrm{EDTANa}_{2}$ However, when the dosage of EDTANa 2 increased to $2000 \mathrm{~g} \mathrm{ha}^{-1}$, phytotoxicity was observed (Figure $2 \mathrm{C}$ ). These results suggested that EDTANa 2 could be used as a safe antifungal agent at low concentration.

A

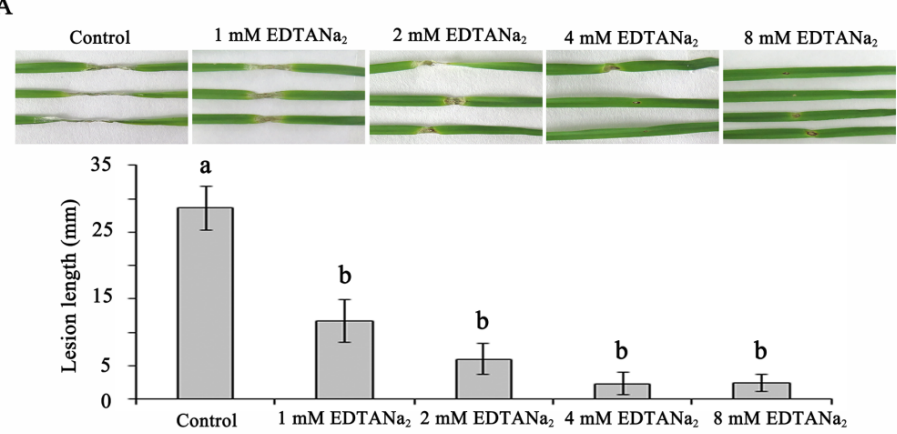

B

C
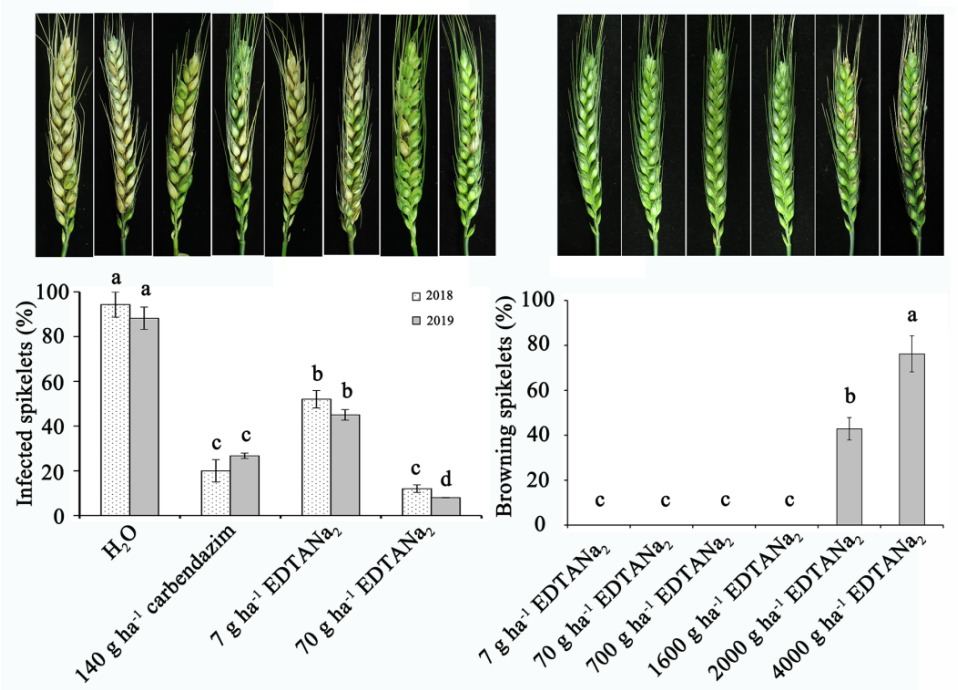

Figure 2. Control effect and phytotoxicity test of EDTANa 2 . (A) Control effect of EDTANa 2 on wheat seedling blight in laboratory. The test was designed with two random replications for each race of plant. Ten seedlings per treatment were inoculated with macroconidia suspension $24 \mathrm{~h}$ after EDTANa $_{2}$ spray. The lesions of diseased leaves were measured and photographed on sixth day post inoculation. Different letters represent a significant difference at $p<0.05$. A linear regression equation of the percentage control effect for each EDTANa 2 concentration was developed using the SPSS 20.0 (IBM, Chicago, IL, USA) statistical package $(y=4.67+3.329 x, \mathrm{R}=0.9476)$. (B) Control effect of EDTANa $_{2}$ on Fusarium head blight in the field. Wheat spikelets (cultivar Huaimai33) were sprayed with water, $40 \%$ carbendazim $\left(140 \mathrm{~g} \mathrm{ha}^{-1}\right)$, or EDTANa 2 . Twenty-four hours later, the spikelets were inoculated via a spray inoculation experiment with a conidial suspension. Each combination of fungicide treatment and fungus was represented by 30 heads. After 21 days, the percentages of infected spikelets were determined, and representative heads were photographed. Values are means \pm SD. Different letters represent a significant difference at $P<0.05$. (C) Phytotoxicity test of EDTANa 2 in the field. Wheat spikelets (cultivar Huaimai33) were sprayed with EDTANa 2 and photographed at 21 days post inoculation. The data are an average \pm standard error from 30 randomly selected heads. The experiment was replicated three times. 


\subsection{EDTANa 2 Decreases DON Biosynthesis and TRI Gene Expression of Fusarium Graminearum In Vitro}

Because the mycotoxin DON is a virulence factor, we investigated the mycotoxin biosynthesis potential of strains under EDTANa 2 treatment. To verify the ability of the $\mathrm{EDTANa}_{2}$ to limit toxin production, DON amounts were measured using a competitive ELISA-approach. As shown in Figure 3A, the DON production in TBI media was significantly inhibited by $0.4 \mathrm{mM}$ and $0.8 \mathrm{mM} \mathrm{EDTANa}_{2}$, about $47 \%$ and $57.3 \%$ lower than the control group, respectively.

A

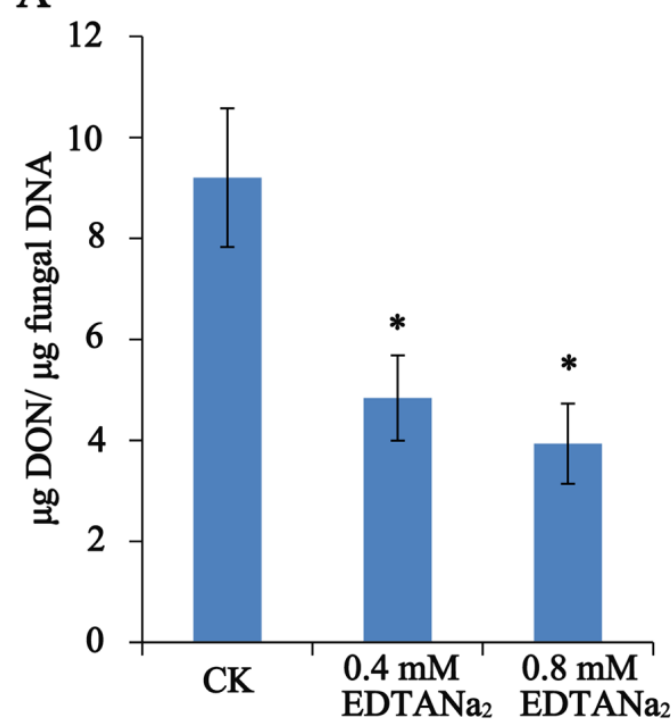

B

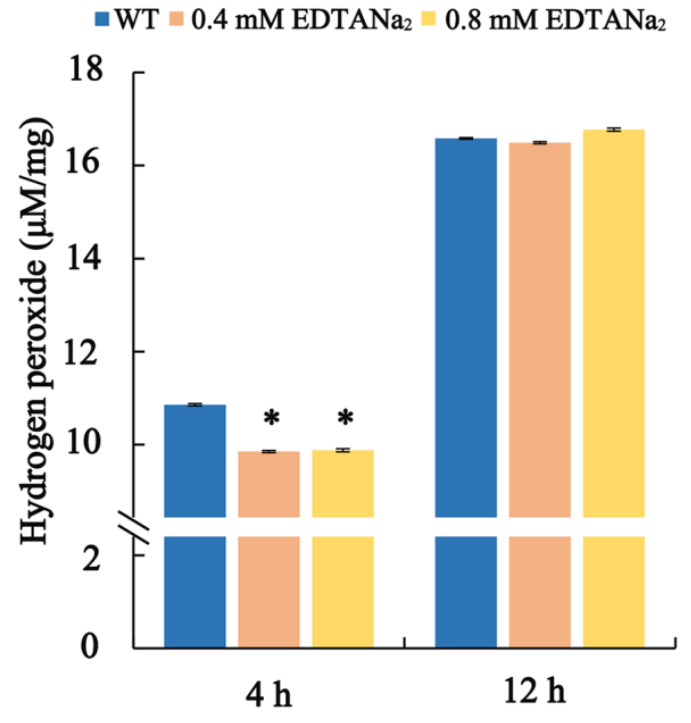

DON transporter

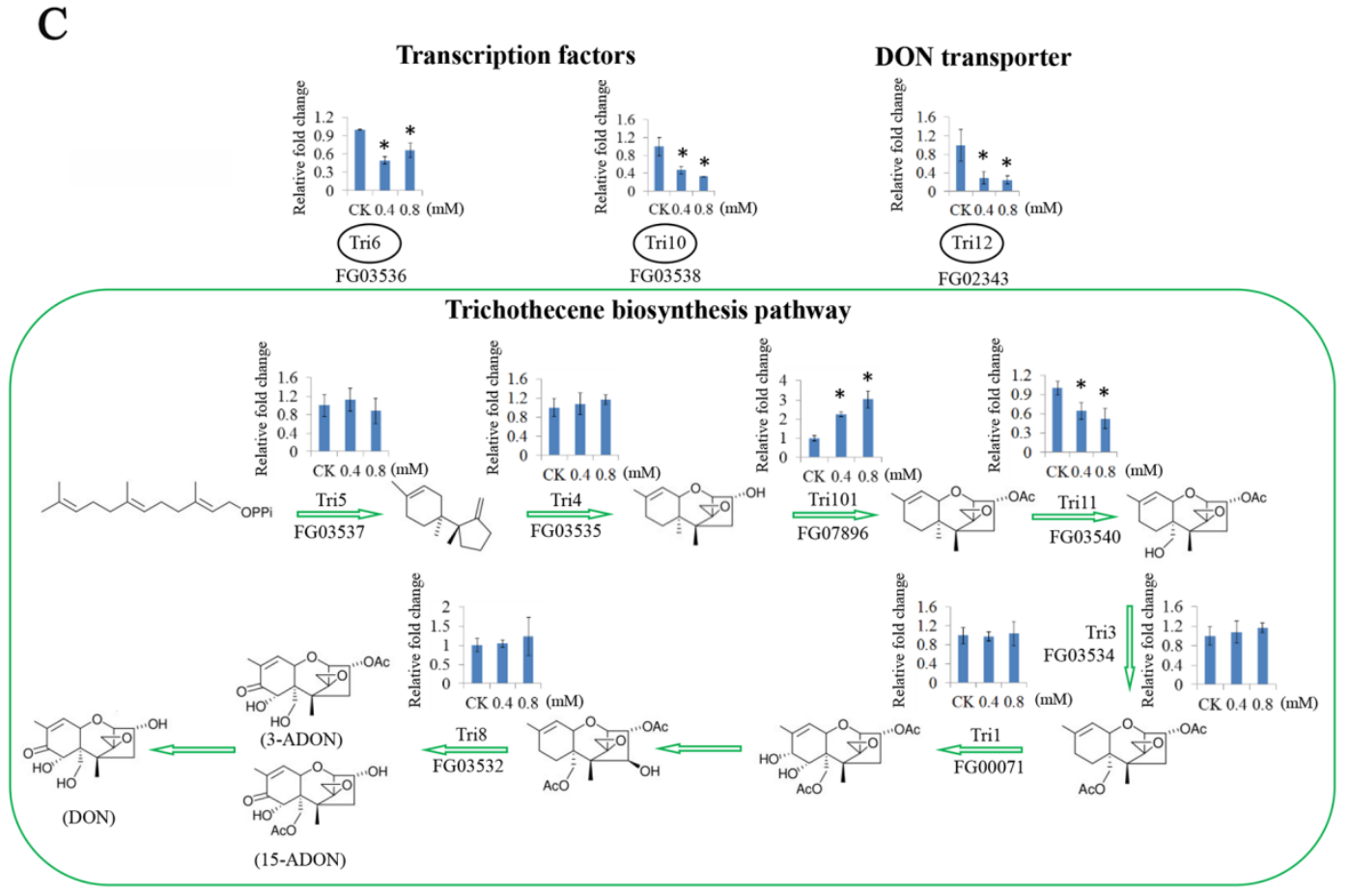

Figure 3. Effect of EDTANa 2 on production of deoxynivalenol (DON) (A), $\mathrm{H}_{2} \mathrm{O}_{2}$ concentrations (B) and TRI genes expression (C). DON content was determined using a competitive ELISA approach $7 \mathrm{~d}$ after start of the experiments. The experiment was repeated three times. $\mathrm{H}_{2} \mathrm{O}_{2}$ was measured at $4 \mathrm{~h}$ and $12 \mathrm{~h}$ and calculated based on a standard curve included in each experiment. TRI gene expression was assayed by qRT-PCR. Hyphae were harvested from 2-day-old TBI cultures (1 day after EDTANa 2 adding). Data are represented as the means \pm SD of three biological replicates (significant differences at $* p<0.05)$. 
As several lines of evidence in the literature corroborate an important role for $\mathrm{H}_{2} \mathrm{O}_{2}$ in induction of toxin production, the accumulation of $\mathrm{H}_{2} \mathrm{O}_{2}$ upon EDTANa $\mathrm{N}_{2}$ application was monitored using an in vitro assay. It showed that adding $0.4 \mathrm{mM}$ and $0.8 \mathrm{mM} \mathrm{EDTANa}_{2}$ resulted in a decreased $\mathrm{H}_{2} \mathrm{O}_{2}$ content in the medium compared to the control as fast as $4 \mathrm{~h}$ after the start of the assay (Figure 3B). This indicated that EDTANa 2 decreased the intracellular oxygen content within a short time after adding to the medium, which may reduce the activation of oxygen to toxin synthesis.

To further reveal the expression profiles of individual genes and their coordination in the trichothecene biosynthesis pathway, we measured the expression of several TRI genes after treating with EDTANa 2 . We found four genes in the trichothecene biosynthesis pathway were significantly down-regulated compared with the control group (Figure 3C). After treating with $0.4 \mathrm{mM}$ EDTANa $_{2}$ at $12 \mathrm{~h}$, the expression of the TRI6 and TRI10 genes, which have been identified as positive transcription factor genes for trichothecene biosynthesis in F. graminearum, decreased by 2- and 2.13-times; The TRI12 gene, which is associated with trichothecene accumulation and resistance in F. graminearum, decreased by 3.45-times compared with the control group; The expression of the TRI11 gene also decreased by 1.56 -times. The inhibitory effect of $0.8 \mathrm{mM} \mathrm{EDTANa}_{2}$ on the TRI genes expression was consistent with that of $0.4 \mathrm{mM} \mathrm{EDTANa}_{2}$. It should be mentioned that the Tri101 gene encoding a trichothecene 3-O-acetyltransferase showed a remarkable upregulation, with 2.24- and 3.02-fold more transcripts after treating with $0.4 \mathrm{mM}$ and $0.8 \mathrm{mM}$ $\mathrm{EDTANa}_{2}$, respectively (Figure $3 \mathrm{C}$ ). These in vitro results suggested that EDTANa ${ }_{2}$ can indeed inhibit DON biosynthesis and may be useful for reducing DON contamination in grains caused by F. graminearum.

\subsection{Ethylenediaminetetraacetic Acid Disodium Salt Affected Cell Wall Formation and Cell Permeability}

The inhibition of Fusarium growth by EDTANa 2 was observed, so we analyzed the cell wall formation and cell permeability of cells grown in the presence of EDTANa ${ }_{2}$. The mycelia treated by EDTANa 2 were sensitive to the preparation condition of scanning electron microscopy (SEM), and were destroyed and lysed with SEM observation (Figure 4A). As shown in Figure 4B, the ultra-structures of the untreated cells exhibited normal electrondense layers and patterns under transmission electron microscopy. In contrast, the cells cultured in $0.075 \mathrm{mM} \mathrm{EDTANa}_{2}$ had a clearly altered cell wall electron density, thickness and ultrastructure. The most notable visual alteration was a thicker cell wall in the treated cells, which topped $573 \mathrm{~nm}$ compared with that of the control cell, which had an average of $142 \mathrm{~nm}$ (the biggest thickness was $153 \mathrm{~nm})(n=20)$. Furthermore, the number of layers in the treated cell wall was reduced, and the electron density declined, whereas three layers were easily recognized in the normal cell wall. In filamentous fungi, chitin, a $\beta-1,4-$ linked polysaccharide of $\mathrm{N}$-acetylglucosamine, is a key structural component of the cell wall [38]. To further analyze the effect of EDTA and EDTANa $a_{2}$ on cell wall formation, we measured the chitin content of $F$. graminearum cell walls after EDTA or EDTANa ${ }_{2}$ treatment. The results illustrated that the EDTA and EDTANa ${ }_{2}$ treatment groups produced only $33.43 \%$ and $25.23 \%$ chitin relative to the hyphal dry weight, values $35.35 \%$ and $51.2 \%$ lower than those of the control group, respectively (Figure 4C). It is noteworthy that EDTANa 2 was more effective than EDTA, which concurred with our above results. 
A

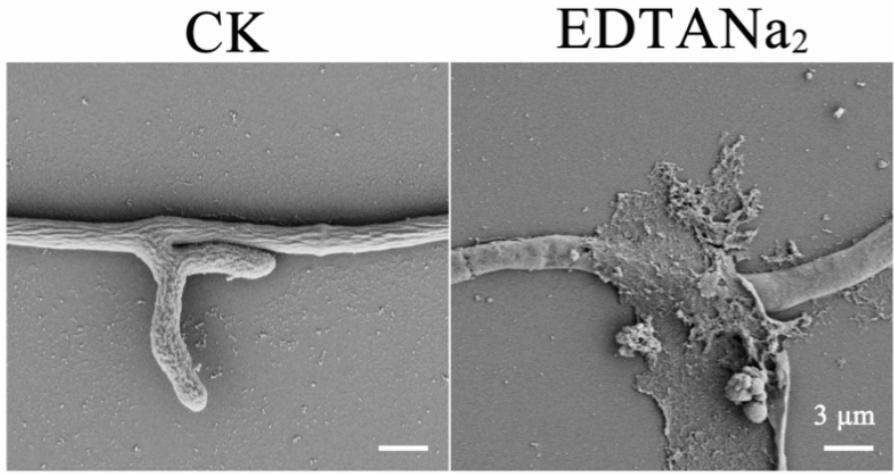

B

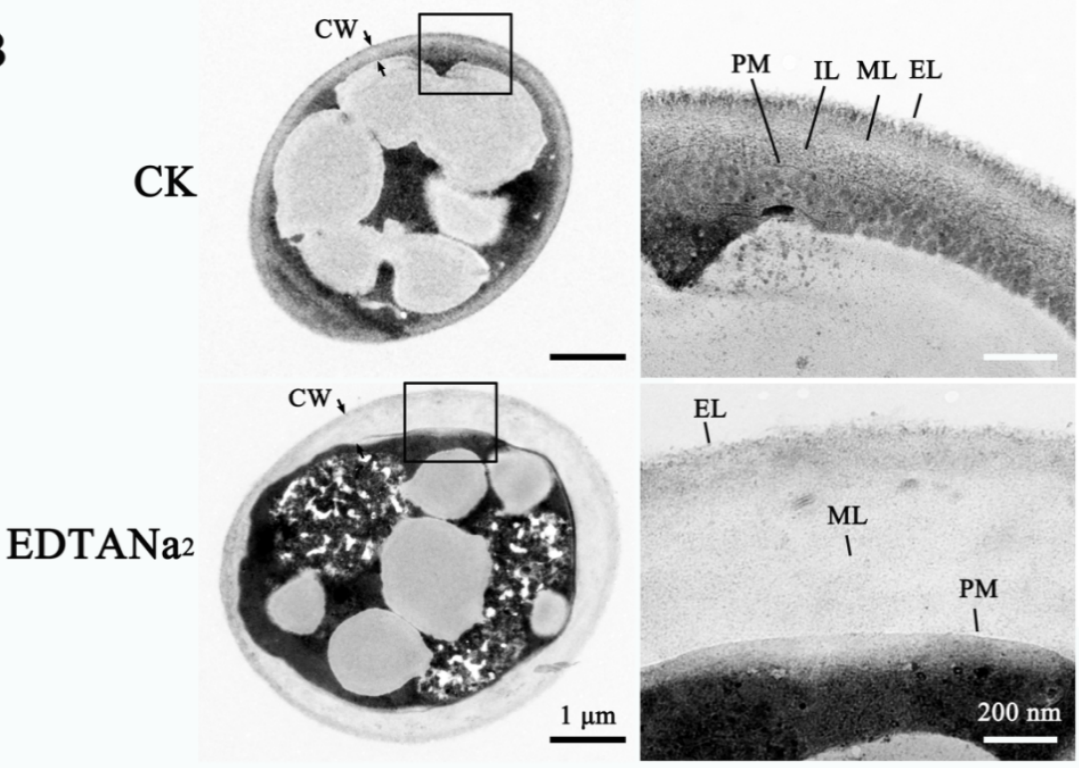

C

D

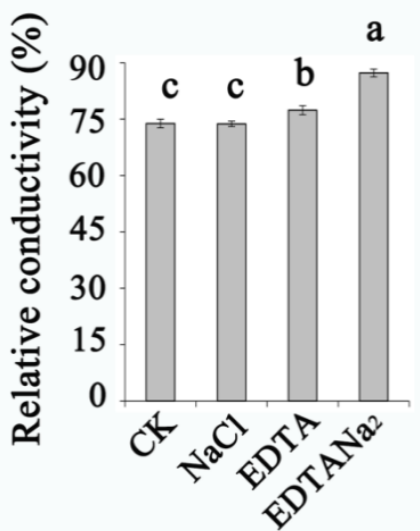

Figure 4. Effects of EDTANa 2 on Fusarium cell wall formation and cell permeability. (A) Scanning electron microscopy of hyphae of Fusarium graminearum treated with or without EDTANa2. (B) Transmission electron microscopy of hyphae of F. graminearum treated with or without EDTANa 2 . The right panel is an enlarged view of the area in the black box in the left panel. CW, cell wall; EL, external electron-dense layer; ML, middle electron-dense layer; IL, internal electron-dense layer; PM, plasma membrane. Chitin content (C) and relative conductivity assay (D) of F. graminearum treated with $0.3 \mathrm{mM} \mathrm{NaCl}, 0.15 \mathrm{mM}$ EDTA or EDTANa $\mathrm{E}_{2}$. The experiment was performed in triplicate. Different letters represent a significant difference at $p<0.05$.

In most cases, the mode of action of antimicrobials against pathogens depends on the destruction of the fungal cell membrane and the resulting increase in cell permeability. The 
change in electrical conductivity reflects the change in the cell membrane permeability of Fusarium. Additionally, our data showed that the relative conductivity of hypha was significantly increased by $11 \%$ and $15 \%$ after $0.15 \mathrm{mM}$ EDTA and $0.15 \mathrm{mM}$ EDTANa 2 treatment compared with that of the control group, respectively (Figure 4D). There was no difference between $0.6 \mathrm{mM} \mathrm{NaCl}$ treatment and the control group. Therefore, EDTA and EDTANa especially EDTANa ${ }_{2}$, indeed affected both cell wall formation and cell permeability and resulted in a decreasing resistance to the external environment in F. graminearum.

2.5. The Inhibitory Effects of Ethylenediaminetetraacetic Acid Disodium Salt against Fusarium are Ameliorated by $\mathrm{Mn}^{2+}$ but not $\mathrm{Mg}^{2+}$ and $\mathrm{Ca}^{2+}$

In order to find out the mechanism of inhibiting effect of EDTANa $a_{2}$, we examined the effect of the saturation of EDTANa $2(0.15 \mathrm{mM})$ by the addition of excess cations $(0.15 \mathrm{mM}$ to $1.2 \mathrm{mM}$ ). As shown in Figure 5A, the adding of $\mathrm{Mn}^{2+}$ increased the biomass of mycelia, but the adding of $\mathrm{Mg}^{2+}$ and $\mathrm{Ca}^{2+}$ had no significant effect on mycelia biomass. In addition, when an additional $0.3 \mathrm{mM} \mathrm{MgCl}_{2}, 0.3 \mathrm{mM} \mathrm{CaCl}_{2}$ or $0.15 \mathrm{mM} \mathrm{FeCl}_{3}$ was added into the media as sources of divalent ions to bind $0.15 \mathrm{mM} \mathrm{EDTANa}_{2}$, mycelial growth was not resumed. $0.15 \mathrm{mM} \mathrm{EDTANa}_{2}$ plus $0.3 \mathrm{mM} \mathrm{Mn}^{2+}$, however, rescued mycelial growth and morphology, which was similar to that in control wells not given EDTANa 2 (Figure 5B). That indicated that the inhibiting effect of EDTANa 2 was related to its function of chelation.

A

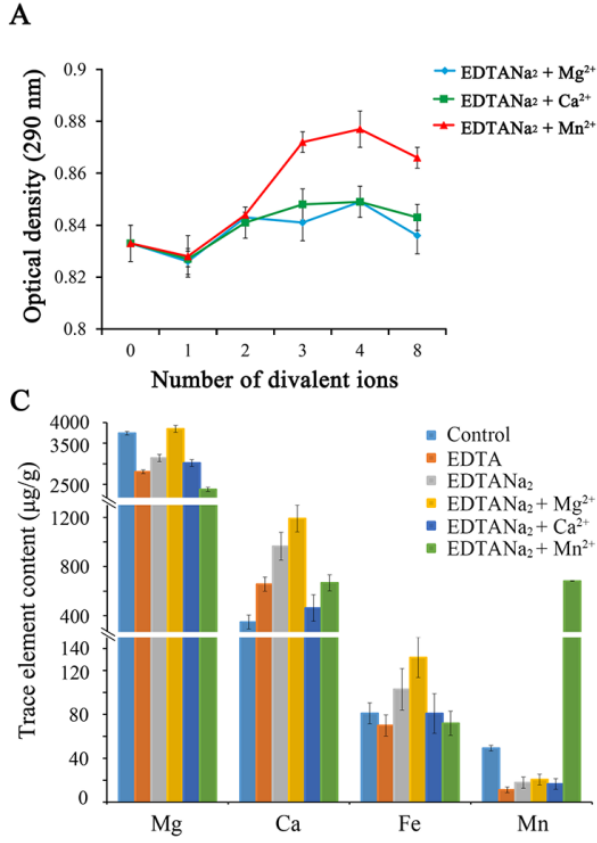

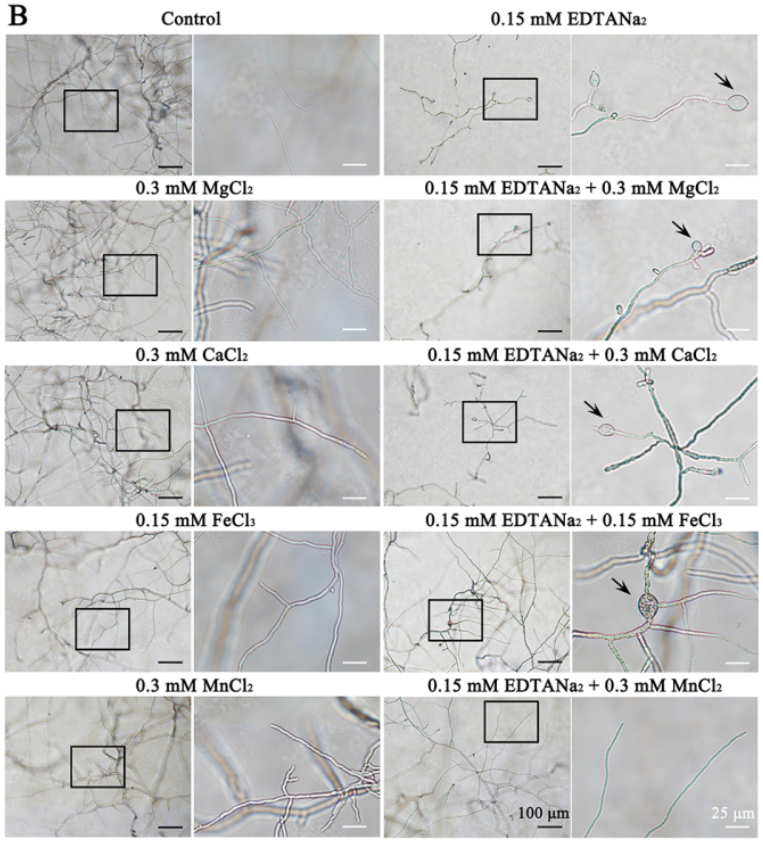

Figure 5. (A) EDTANa 2 saturation with $\mathrm{Mg}^{2+}, \mathrm{Ca}^{2+}$ and $\mathrm{Mn}^{2+}$ induces the resumption of mycelial growth. The mycelial biomass was measured after $52 \mathrm{~h}$ of incubation as from $\mathrm{MgCl}_{2}, \mathrm{CaCl}_{2}$ or $\mathrm{MnCl}_{2}$ adding. Mycelial biomass was expressed as absorbance. (B) Effects of different cations on EDTANa 2 activity against Fusarium graminearum. The right panel is an enlarged view of the area in the black box in the left panel. The arrows indicate conglobate structures. The same amounts of cations were added to the medium as controls. The experiment was repeated three times with the same patterns. (C) Concentration of selected trace elements in fungi treated with $0.15 \mathrm{mM} \mathrm{EDTANa}_{2}$ or $0.15 \mathrm{mM} \mathrm{EDTANa}_{2}$ plus $0.3 \mathrm{mM}$ additional cations. Mycelial biomass and trace element assays were performed using three biological replicates for each group.

We further measured the trace element content of Fusarium hyphae in different treatments. As shown in Figure 5C, when EDTA and EDTANa 2 were added to the medium, the $\mathrm{Mg}$ and Mn elements decreased as expected. However, the contents of $\mathrm{Ca}$ and Fe elements were not significantly changed after the addition of EDTA and EDTANa 2 . When an additional $\mathrm{Mg}^{2+}$ or $\mathrm{Ca}^{2+}$ was added into the medium containing EDTANa ${ }_{2}$, all the trace el- 
ements, except Mn, increased or showed no difference compared with the untreated group. The Mn was always in a deficient state in the mycelia treated by EDTA and EDTANa 2 unless $\mathrm{Mn}^{2+}$ was added into the medium. These results suggested that intracellular $\mathrm{Mn}^{2+}$ was chelated by EDTANa 2 , resulting in cell wall and cell membrane defects.

\subsection{Chitin Synthases are More Active in F. graminearum When $\mathrm{Mn}^{2+}$ Is Used as a Cofactor}

To further study the mechanism of the EDTANa 2 control effect, chitin synthases were extracted for enzymatic analysis. Unlike most chitin synthases in other fungi that used $\mathrm{Mg}^{2+}$ as the cofactor, chitin synthases in F. graminearum were more active when $\mathrm{Mn}^{2+}$ was used at the active site. The chitin synthases with $5 \mathrm{mM} \mathrm{Mn}^{2+}$ had a $26 \%$ higher activity than that with $5 \mathrm{mM} \mathrm{Mg}^{2+}$, indicating that chitin synthases in $F$. graminearum may use $\mathrm{Mn}^{2+}$ as the cofactor. The addition of $0.25 \mathrm{mM} \mathrm{EDTANa}_{2}$ into the reaction systems could decrease enzymatic activity by $40 \%$ and $44 \%$ after chelation of $\mathrm{Mn}^{2+}$ and $\mathrm{Mg}^{2+}$, respectively. However, chitin synthase in the $\mathrm{Mn}^{2+}$ reaction system still had a $33 \%$ higher activity than that in the $\mathrm{Mg}^{2+}$ reaction system. When the EDTANa 2 concentration was increased to $1 \mathrm{mM}$, the activity of chitin synthase in the $\mathrm{Mn}^{2+}$ and $\mathrm{Mg}^{2+}$ reaction systems decreased to 0.09 and $0.11 \mathrm{nmol} \mathrm{GlcNAc}{ }^{-1} \mathrm{mg}^{-1}$, respectively (Figure 6A). Consistent with this, the metal ion addition experiment showed that the chitin content returned to normal levels after the addition of $0.15 \mathrm{mM} \mathrm{Mn}^{2+}$ to SNA culture medium (containing $0.15 \mathrm{mM} \mathrm{EDTANa}_{2}$ ). While wells adding $\mathrm{Mg}^{2+}$ or $\mathrm{Ca}^{2+}$ produced equivalent chitin to wells adding EDTANa 2 only, a $35-50 \%$ reduction was observed compared to the control group (Figure 6B).

A

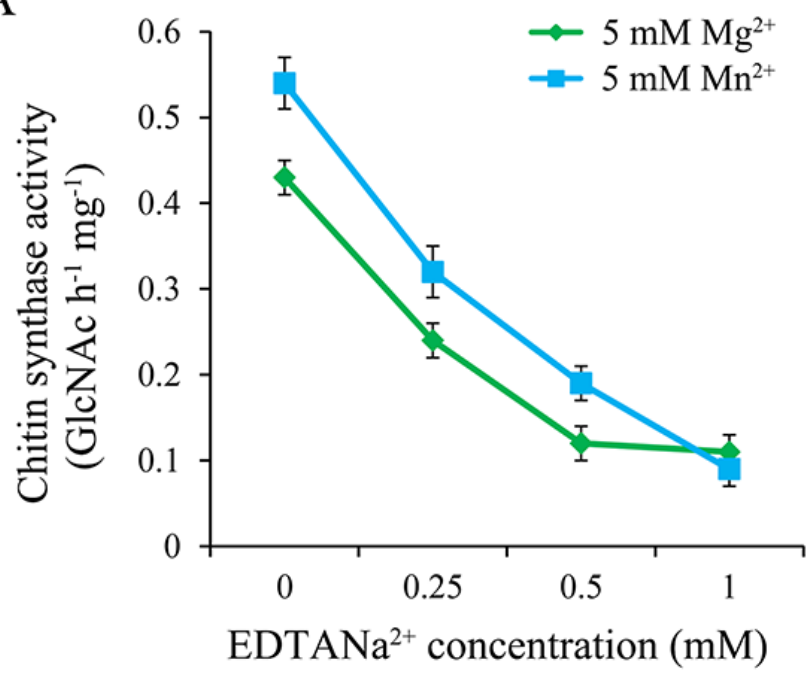

$\mathrm{B}$

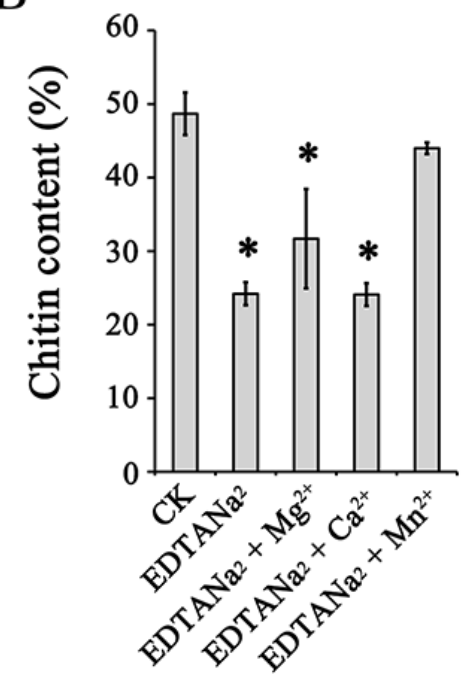

Figure 6. Chitin synthase activity and chitin content assay of Fusarium graminearum. (A) Chitin synthase activity was measured following $\left({ }^{14} \mathrm{C}\right)$ GlcNAc incorporation into the filter-retainable polymer in the presence of $\mathrm{Mg}^{2+} \mathrm{Or} \mathrm{Mn}^{2+}$. Data are expressed as nmol of GlcNAc incorporated per hour per mg of protein. (B) Mycelia were treated with EDTANa ED $^{2}$ EDTANa $_{2}$ with additional cations. EDTANa $2(0.15 \mathrm{mM})$ was saturated by adding $\mathrm{Mg}^{2+}, \mathrm{Ca}^{2+}$ or $\mathrm{Mn}^{2+}(0.45 \mathrm{mM})$ to SNA media. Data are represented as the means \pm SD of three biological replicates ${ }^{*}$ indicates significant differences at $p<0.05$ compared to CK).

\section{Discussion}

The genus Fusarium, which is pathogenic and toxic to plants and humans, is one of the most economically damaging fungal genera. Fusarium colonizes a wide range of environments, and control of Fusarium floral infections remains problematic. Some fungicides, including triazoles, benzimidazoles and strobilurins, are moderately effective, but reports of fungicide failure resulting from resistance have increased since the late 1960s $[39,40]$. To make matters worse, the development of new fungicides is much slower than the appearance of fungicide resistance in Fusarium populations [41,42]. Here, a 
nonantibiotic drug, EDTANa 2 , exhibited novel antifungal activity against $F$. graminearum and DON production. Through combined analyses of morphology, DON content and TRI gene expression detection, chitin detection, cell permeability, transmission electron microscopy and field experiments, we demonstrated that EDTANa ${ }_{2}$ destroyed cell wall and cytomembrane integrity and inhibited TRI gene expression in F. graminearum, and the antifungal effect of EDTANa 2 relied on $\mathrm{Mn}^{2+}$-chelating abilities.

EDTA is considered as an ion chelator, and it has been recommended as antimicrobial agent against bacteria and C. albicans [43-45]. The $\mathrm{EC}_{50}$ value of EDTANa 2 for $F$. graminearum is $107.88 \mathrm{mg} \mathrm{L}^{-1}$, which is higher than that of carbendazim (about $0.5 \mathrm{mg} \mathrm{L}^{-1}$ ). The field test, however, shows that $70 \mathrm{~g} \mathrm{ha}^{-1}$ EDTANa $_{2}$ decreased the incidence of disease by $70 \%$ compared to $140 \mathrm{~g} \mathrm{ha}^{-1}$ carbendazim treatment. As DON is an important virulence factor in wheat, previous studies suggest that significant decreases in FHB incidence in field situations are possible with proper DON inhibited fungicide applications [46]. In our study, the DON production was significantly inhibited by EDTANa ${ }_{2}$, which may increase the antifungal effects on FHB.

The fungal cell wall protects the cell against osmotic pressure and other environmental stresses and is considered the carbohydrate armor of the fungal cell [47]. After EDTANa treatment, all layers across the cell wall were affected, and the chitin content was decreased in Fusarium. In addition, the membrane permeability increased significantly when Fusarium was cultured in medium containing EDTANa2. This suggests that the fungal cells became more sensitive to changes in environmental stresses with EDTANa $\mathrm{N}_{2}$ treatment.

Our next question was which divalent cation was chelated by EDTANa 2 and then caused chitin content reduction and cell wall defects in Fusarium. There have been reports that calcium-binding agents inhibit Cryptococcus neoformans and C. albicans by disrupting the assembly of the polysaccharide capsule through $\mathrm{Mg}^{2+}$ and $\mathrm{Ca}^{2+}$ chelation $[31,48,49]$. However, the results in our paper showed that EDTANa 2 chelated $\mathrm{Mn}^{2+}$ and resulted in a reduction of chitin synthesis. In fungi, chitin is synthesized by chitin synthase, whose activities are known to depend upon the presence of a divalent cation [50,51]. Chitin synthases (CHSs) in Fusarium were previously classified into seven categories [52]. Different chitin synthases are distinct in their responses to the divalent cation, for example, Chs2 and Chs3 are stimulated, while Chs1 is inhibited by $\mathrm{Co}^{2+}$ in Saccharomyces cerevisiae [53]. On the basis of the data obtained in our study, it may be logical to assume that $\mathrm{Mn}^{2+}$ is essential for the main chitin synthase of Fusarium. EDTA had a fungistatic effect on F. fujikuroi growth, a pathogen causing bakanae disease, and its action was largely suppressed by $\mathrm{Mn}^{2+}$ and slightly by $\mathrm{Ca}^{2+}$ [54]. Combining with our findings, we can speculate that this kind of chelating agent, such as EDTA and EDTANa 2 inhibits Fusarium spp. mainly because of $\mathrm{Mn}^{2+}$ deficiency.

In summary, EDTANa 2 inhibits DON production and disrupts the cell wall and cell membrane functionality of Fusarium, an effect that appears to mainly result from $\mathrm{Mn}^{2+}$ chelation. The results of our study provided new material and candidate compound against Fusarium in crop protection.

\section{Materials and Methods}

\subsection{Fungi, Plants, and Culture Conditions}

Fusarium graminearum strains PH-1, F. asiaticum strain 2021, F. acuminatum, F. avenaceum, F. concentricum, F. culmorum, F. equiseti, F. fujikuroi, F. lateritium, F. oxysporum, F. proliferatum, F. solani and F. verticillioides (Figure S1, Table S2) used in this study were stored in our laboratory [55]. The wheat variety Huaimai33 was maintained in our laboratory. Carboxymethyl cellulose (CMC) broth [56] and SNA medium $\left(0.1 \% \mathrm{KH}_{2} \mathrm{PO}_{4}, 0.1 \% \mathrm{KNO}_{3}\right.$, $0.05 \% \mathrm{MgSO}_{4} \cdot 7 \mathrm{H}_{2} \mathrm{O}, 0.05 \% \mathrm{KCl}, 0.02 \%$ glucose, and $0.02 \%$ sucrose) were used for conidia production and assessments of mycelial growth, respectively. EDTA (99\%) and inorganic metal salts were purchased from Sigma-Aldrich (St. Louis, MO, USA). 


\subsection{Control Effect Measurement on Wheat Seedling Blight}

The test was evaluated under controlled conditions using a completely randomized design with two replications for each treatment. Ten seedlings per treatment were inoculated on the fully expanded primary leaves $8 \mathrm{~d}$ after Huaimai33 planting. The EDTANa 2 was sprayed on leaves at different concentration from 0.5 to $8 \mathrm{mM}$. After $24 \mathrm{~h}$, leaves were punctured and inoculated with three microliter of macroconidia suspension $\left(1 \times 10^{6}\right.$ spores $\left.\mathrm{mL}^{-1}\right)$. The lesions of diseased leaves were measured and photographed at 6th day post inoculation. Duncan's multiple comparison test (SPSS20.0, IBM, Chicago, IL, USA) with a significant difference set as $P<0.05$ was used to compare sample means. Mean values and standard deviations were reported. The differences between means with $P$ less than 0.05 were considered statistically significant. The control effect was characterized by linear regression analysis $(R=0.94)$ using the SPSS statistical package.

\subsection{Control Effect Measurement on Fusarium Head Blight and Phytotoxicity Field Test}

The field study was conducted for two years (2018 and 2019) at the same location with different randomizations for each year (Table 1). Wheat (Triticum aestivum L. cv. Huaimai33) was grown on the experimental farm of Nanjing Agricultural University. At Zadok's growth stage (ZGS) 65, while more than half of the wheat spikes were in bloom, field plots were arranged in a randomized block, which was designed with three 3 plots (each plot was $4 \times 5 \mathrm{~m}$ ). The treatments were as follows: (1) a control consisting of water; (2) $140 \mathrm{~g} \mathrm{ha}^{-1}$ carbendazim; (3) $7 \mathrm{~g} \mathrm{ha}^{-1}$ EDTANa $_{2}$; (4) $70 \mathrm{~g} \mathrm{ha}^{-1}$ EDTANa $_{2} .7-4000 \mathrm{~g} \mathrm{ha}^{-1}$ EDTANa $_{2}$ were used for phytotoxicity assays. For floral spray inoculations, each plant was sprayed with $0.5 \mathrm{~mL}$ of $1 \times 10^{4}$ spores $\mathrm{mL}^{-1}$ F. graminearum strain PH-1 conidia $24 \mathrm{~h}$ after $\mathrm{EDTANa}_{2}$ spray treatment. Pathogenicity assays were performed 14 or 21 days after EDTANa 2 spray treatment as described previously [57]. The influence of EDTANa 2 on wheat was tested by assessing browning spikelets. Thirty wheat heads were randomly selected to calculate the browning spikelets ratio for each concentration of EDTANa 2 . The browning spikelets ratio was defined as follows: browning spikelet $(\%)=$ browning spikelets $/$ total spikelets. The experiment was replicated three times.

Table 1. Climate conditions in the field study.

\begin{tabular}{|c|c|c|c|c|c|}
\hline \multirow{2}{*}{ Year } & \multirow{2}{*}{ Experimental Date } & \multirow{2}{*}{ Rainy Period } & \multicolumn{3}{|c|}{ Temperature a $\left({ }^{\circ} \mathrm{C}\right)$} \\
\hline & & & $\mathrm{T}_{\mathrm{av}}$ & $\mathbf{T}_{\max }$ & $T_{\text {min }}$ \\
\hline 2018 & 20 Apr.-4 May. & 21 Apr.-23 Apr., 29 Apr.-1 May & 21 & 30 & 11 \\
\hline 2019 & 20 Apr.-11 May. & 21 Apr., 27 Apr. and 28 Apr. & 18 & 30 & 9 \\
\hline
\end{tabular}

\subsection{Mycelial Growth Inhibition by EDTANa 2}

For a fungicide-sensitivity assay in the laboratory, a three-day-old mycelial plug $(5 \mathrm{mM}$ in diameter) was placed in the center of a minimal medium (MM) $\left(10 \mathrm{mM} \mathrm{K}_{2} \mathrm{HPO}_{4}, 10 \mathrm{mM}\right.$ $\mathrm{KH}_{2} \mathrm{PO}_{4}, 2.5 \mathrm{mM} \mathrm{NaCl}, 4 \mathrm{mM} \mathrm{NH} \mathrm{NO}_{3}, 10 \mathrm{mM}$ glucose) plate amended with EDTANa at $0,0.1,0.2,0.4,0.8,1.6 \mathrm{mM}\left(0,37.2,74.4,148.8,297.6\right.$, or $\left.595.2 \mathrm{mg} \mathrm{L}^{-1}\right)$. After $4 \mathrm{~d}$ at $25^{\circ} \mathrm{C}$, the colony diameters in two perpendicular directions of each plate were measured and averaged. Each combination of strain and concentration was represented by three biological replicates. The median effective concentration $\left(\mathrm{EC}_{50}\right)$ value was calculated with DPS software (version 7.0, DPS Inc., Cary, NC, USA).

\subsection{Optical, Scanning Electron Microscopy and Transmission Electron Microscopy Observation}

Morphological observation of mycelia was performed using an inverted Olympus IX71 microscope (Olympus Canada, Markham, ON, Canada). Images were captured and analyzed by Image-Pro Plus 4.5 software (Media Cybernetics, Silver Spring, Maryland). Scanning electron microscopy (SEM) and transmission electron microscopy (TEM) were 
carried out using hyphae germinated from spores in SNA supplemented with $0.15 \mathrm{mM}$ EDTANa $_{2}$ at $25{ }^{\circ} \mathrm{C}$ for $24 \mathrm{~h}$. All the cultures were performed in triplicate. For SEM determination, mycelia were fixed with $2.5 \%$ glutaraldehyde in $0.1 \mathrm{M}$ sodium phosphate buffer ( $\mathrm{pH} 7.2$ ) at $4{ }^{\circ} \mathrm{C}$ for $12 \mathrm{~h}$. The samples were then washed with sodium phosphate buffer $(0.1 \mathrm{M}, \mathrm{pH} 7.2)$ and treated with $1 \%$ osmium tetroxide in sodium phosphate buffer for $1 \mathrm{~h}$, subjected to gradual dehydration in ethanol (70,80, 90 and 100\%), and dried to the critical point (CPD 030 Critical Point BALTEC Dryer, Leica Microsystems, Liechtenstein). After drying, the samples were glued on stubs using carbon tape and coated with gold (Sputter Coater BALTEC SDC 050, Leica Microsystems, Liechtenstein). For TEM determination, sections were prepared and visualized using a H-7650 transmission electron microscope (Hitachi, Tokyo, Japan) as described by Song et al. [57].

\subsection{Measurement of $\mathrm{H}_{2} \mathrm{O}_{2}$ and $\mathrm{DON}$}

$\mathrm{H}_{2} \mathrm{O}_{2}$ formation in the fungicide experiments was measured $4 \mathrm{~h}$ and $12 \mathrm{~h}$ after $0.4 \mathrm{mM}$ or $0.8 \mathrm{mM}$ EDTANa 2 treatment using a TMB (tri-methyl-benzidin) assay [58]. $\mathrm{H}_{2} \mathrm{O}_{2}$ formation was determined by measuring the absorbance at $620 \mathrm{~nm}$ in duplicate in each time point and in three independent experiments. In each experiment, a standard curve of pure $\mathrm{H}_{2} \mathrm{O}_{2}$ was added in a concentration range of $0.01 \mathrm{mM}$ up to $100 \mathrm{mM}$. The $\mathrm{H}_{2} \mathrm{O}_{2}$ formed in the in vitro assay was calculated based on this standard curve.

DON production in TBI cultures was assayed with a competitive ELISA-based DON detection plate kit (Wise, Zhenjiang, China) according to previous studies [59]. Ten microliter of conidia $\left(1.5 \times 10^{7} / \mathrm{mL}\right)$ were inoculated in $30 \mathrm{~mL}$ TBI and cultured at $28^{\circ} \mathrm{C}$ for $24 \mathrm{~h}$ in dark, and then $0.4 \mathrm{mM}$ or $0.8 \mathrm{mM} \mathrm{EDTANa}_{2}$ was added and cultured for additional 6 days. The experiment was repeated three times. To assay TRI gene expression, hyphae were harvested from 2-day-old TBI cultures (1 day after EDTANa 2 adding) and used for RNA isolation. qPCR was performed as previously describe (Table S3) [57]. The tubulin gene of $F$. graminearum was used as the internal control. The results were calculated with the data from three biological replicates.

\subsection{Chitin Content, Chitin Synthase Activity and Cell Membrane Permeability Measurement}

Macroconidia $\left(10^{4} \mathrm{~mL}^{-1}\right)$ were cultured in SNA, SNA amended with $0.15 \mathrm{mM}$ EDTA or SNA amended with $0.15 \mathrm{mM} \mathrm{EDTANa}_{2}$ for 7 days and were used for chitin determination as previously described [57]. Fresh mycelium cultured in Czapek's medium ( $3 \mathrm{~g} \mathrm{~L}^{-1}$ of $\mathrm{NaNO}_{3}, 1.31 \mathrm{~g} \mathrm{~L}^{-1}$ of $\mathrm{K}_{2} \mathrm{HPO}_{4}, 0.5 \mathrm{~g} \mathrm{~L}^{-1}$ of $\mathrm{KCl}, 0.5 \mathrm{~g} \mathrm{~L}^{-1}$ of $\mathrm{MgSO}_{4} \cdot 7 \mathrm{H}_{2} \mathrm{O}, 0.01 \mathrm{~g} \mathrm{~L}^{-1}$ of FeSO4. $7 \mathrm{H}_{2} \mathrm{O}, 30 \mathrm{~g} \mathrm{~L}^{-1}$ of sucrose, $\mathrm{pH}$ 7.2) for $5 \mathrm{~d}$ were collected and finely ground with liquid nitrogen for chitin synthase extraction. Chitin synthase activity was extracted and measured according to Song et al. [57] with some modifications. Chitin synthase activity was measured by following $\left({ }^{14} \mathrm{C}\right)$ GlcNAc incorporation into the filter-retainable polymer in the presence of $0-1 \mathrm{mM}$ EDTANa 2 plus $5 \mathrm{mM} \mathrm{Mg}^{2+}$ or $\mathrm{Mn}^{2+}$. To measure the cell membrane permeability, macroconidia (final concentration was $10^{3} \mathrm{~mL}^{-1}$ ) were inoculated into SNA, SNA with $0.3 \mathrm{mM} \mathrm{NaCl}$, SNA with $0.15 \mathrm{mM}$ EDTA or SNA with $0.15 \mathrm{mM}$ $\mathrm{EDTANa}_{2}$ at $25{ }^{\circ} \mathrm{C}$ for 7 days. The conductivity was measured with a conductometer (CON510 Eutech/Oakton, Singapore) as described previously [60]. The conductivity of mycelia boiled for $5 \mathrm{~min}$ represented the final conductivity. The relative conductivity was calculated as follows: relative conductivity $(\%)=$ conductivity $/$ final conductivity $\times 100$. Three biological replicates were tested for each treatment.

\subsection{Fungicidal Activity of EDTANa $(n)$ against Fusarium spp.}

Ten microliters of spores $\left(10^{4} \mathrm{~mL}^{-1}\right)$ of F. graminearum PH-1 were plated in a 96-well flat bottom culture plate containing $0.15 \mathrm{mM}$ EDTA, EDTANa $2, \mathrm{EDTANa}_{3}$ or EDTANa $\mathrm{EN}_{4}$ in $100 \mu \mathrm{L}$ of SNA medium ( $\mathrm{pH}$ 4.2). The plates were cultured at $25^{\circ} \mathrm{C}$ for $24 \mathrm{~h}$ and observed using an inverted microscope. The growth and morphology of mycelia were photographed and compared among treatments using NIS-Elements AR software (version 3.2, Nikon, Tokyo, Japan). The experiment was replicated three times. 
The determination of the minimum inhibitory concentration (MIC) was performed using 96-well microtiter plates. The Fusarium spp. (listed in 'Fungi, plants, and culture conditions') fungal inoculated in 96-well microtiter plates were treated with EDTANa at different concentrations and incubated for 24 or $36 \mathrm{~h}$. The lowest concentration that demonstrated no visible growth was determined as the MIC. Measurements were repeated three times.

\subsection{Effect of Metal Ions on EDTANa 2 Activity}

To assess whether cations would ameliorate the inhibitory effects of EDTANa 2 on mycelial growth and chitin synthesis, an additional $0.3 \mathrm{mM} \mathrm{MgCl} 2,0.3 \mathrm{mM} \mathrm{CaCl}, 0.3 \mathrm{mM}$ $\mathrm{MnCl}_{2}$ or $0.15 \mathrm{mM} \mathrm{FeCl}_{3}$ was added into SNA medium separately to bind the preadded $0.15 \mathrm{mM}$ EDTANa 2 , followed by inoculation at $25{ }^{\circ} \mathrm{C}$ for $24 \mathrm{~h}$ and subsequent microexamination. Corresponding amounts of $\mathrm{MgCl}_{2}, \mathrm{CaCl}_{2}, \mathrm{MnCl}_{2}$ or $\mathrm{FeCl}_{3}$ were used as controls. Subsequently, a series of $\mathrm{MgCl}_{2}, \mathrm{CaCl}_{2}$ or $\mathrm{MnCl}_{2}$ concentrations $(0,0.15,0.3$, $0.45,0.6,1.2 \mathrm{mM}$ ) was added to the media to saturate the $0.15 \mathrm{mM} \mathrm{EDTANa} 2$ to different degrees, and the fungi were cultured for $52 \mathrm{~h}$ to measure the mycelial biomass at $\mathrm{OD}_{290}$. The mycelia that were treated with $0.3 \mathrm{mM}$ cations were collected at $7 \mathrm{~d}$, frozen and dried for chitin content and trace element measurements [61]. Three independent experiments were performed, and the average was calculated.

\subsection{Statistical Analysis}

Statistical analysis was performed using Duncan's multiple comparison test (for multiple comparisons) and Student's $t$-test, all at a significance level of 0.05 .

Supplementary Materials: The following are available online at https: / /www.mdpi.com/2072-6 651/13/1/17/s1, Table S1: Minimum inhibitory concentrations of EDTANa 2 ; Table S2: Strains used in this study; Table S3: Primers used in TRI genes qPCR; Figure S1: Internal transcribed spacer (ITS) sequences alignment of Fusarium isolates used in this study. ITS sequences of different strains were amplified using primers ITS-F/ITS-R (ITS-F: TCCGTAGGTGAACCTGCGG, ITS-R: TCCTCCGCTTATTGATATGC). Sequences alignment was performed using NCBI Blastn (https: / / blast.ncbi.nlm.nih.gov / Blast.cgi) with default parameters.

Author Contributions: M.Z. conceived and designed the experiments. X.-S.S., K.-X.G. and J.G. performed the experiments and analyzed the data. J.-X.W. and S.-C.D. contributed reagents and materials. X.-S.S. wrote and revised the manuscript. All authors have read and agreed to the published version of the manuscript.

Funding: This research was supported by the National Natural Science Foundation of China (31730072) and the Fundamental Research Funds for the Central Universities (KYXK202011).

Conflicts of Interest: The authors declare no conflict of interest.

\section{References}

1. Ma, L.J.; Geiser, D.M.; Proctor, R.H.; Rooney, A.P.; O’Donnell, K.; Trail, F.; Gardiner, D.M.; Manners, J.M.; Kazan, K. Fusarium pathogenomics. Annu. Rev. Microbiol. 2013, 67, 399-416. [CrossRef] [PubMed]

2. Summerell, B.A. Resolving Fusarium: Current status of the genus. Annu. Rev. Phytopathol. 2019, 25, 323-339. [CrossRef] [PubMed]

3. Nelson, P.E.; Dignani, M.C.; Anaissie, E.J. Taxonomy, biology, and clinical aspects of Fusarium species. Clin. Microbiol. Rev. 1994, 7, 479-504. [CrossRef] [PubMed]

4. Bai, G.H.; Shaner, G. Management and resistance in wheat and barley to Fusarium head blight. Annu. Rev. Phytopathol. 2004, 42, 135-161. [CrossRef] [PubMed]

5. Gordon, T.R. Fusarium oxysporum and the Fusarium Wilt Syndrome. Annu. Rev. Phytopathol. 2017, 55, 23-39. [CrossRef] [PubMed]

6. Kazan, K.; Gardiner, D.M.; Manners, J.M. On the trail of a cereal killer: Recent advances in Fusarium graminearum pathogenomics and host resistance. Mol. Plant. Pathol. 2012, 13, 399-413. [CrossRef]

7. Loffler, M.; Kessel, B.; Ouzunova, M.; Miedaner, T. Population parameters for resistance to Fusarium graminearum and Fusarium verticillioides ear rot among large sets of early, mid-late and late maturing European maize (Zea mays L.) inbred lines. Theor. Appl. Genet. 2010, 120, 1053-1062. [CrossRef]

8. Xu, X.; Nicholson, P. Community ecology of fungal pathogens causing wheat head blight. Annu. Rev. Phytopathol. 2009, 47, 83-103. [CrossRef] 
9. $\quad$ Edwards, J.E., Jr.; Bodey, G.P.; Bowden, R.A.; Buchner, T.; de Pauw, B.E.; Filler, S.G.; Ghannoum, M.A.; Glauser, M.; Herbrecht, R.; Kauffman, C.A.; et al. International conference for the development of a consensus on the management and prevention of severe candidal infections. Clin. Infect Dis. 1997, 25, 43-59. [CrossRef]

10. Treikale, O.; Priekule, I.; Javoisha, B.; Lazareva, L. Fusarium head blight: Distribution in wheat in Latvia. Commun. Agric. Appl. Biol. Sci. 2010, 75, 627-634.

11. Pestka, J.J. Deoxynivalenol: Mechanisms of action, human exposure, and toxicological relevance. Arch. Toxicol. 2010, 84, 663-679. [CrossRef] [PubMed]

12. Woloshuk, C.P.; Shim, W.B. Aflatoxins, fumonisins, and trichothecenes: A convergence of knowledge. Fems. Microbiol. Rev. 2013, 37, 94-109. [CrossRef] [PubMed]

13. Brauer, E.K.; Balcerzak, M.; Rocheleau, H.; Leung, W.; Schernthaner, J.; Subramaniam, R.; Ouellet, T. Genome editing of a deoxynivalenol-induced transcription factor confers resistance to Fusarium graminearum in wheat. Mol. Plant Microbe Interact. 2020, 33, 553-560. [CrossRef] [PubMed]

14. Dill-Macky, R.; Jones, R.K. The effect of previous crop residues and tillage on Fusarium head blight of wheat. Plant Dis. 2000, 84, 71-76. [CrossRef]

15. McMullen, M.; Bergstrom, G.; De Wolf, E.; Dill-Macky, R.; Hershman, D.; Shaner, G.; Van Sanford, D. A unified effort to fight an enemy of wheat and barley: Fusarium head blight. Plant Dis. 2012, 96, 1712-1728. [CrossRef]

16. D'Angelo, D.L.; Bradley, C.A.; Ames, K.A.; Willyerd, K.T.; Madden, L.V.; Paul, P.A. Efficacy of fungicide applications during and after anthesis against Fusarium head blight and deoxynivalenol in soft red winter wheat. Plant Dis. 2014, 98, 1387-1397. [CrossRef]

17. Zhang, Y.J.; Yu, J.J.; Zhang, Y.N.; Zhang, X.; Cheng, C.J.; Wang, J.X.; Hollomon, D.W.; Fan, P.S.; Zhou, M.G. Effect of carbendazim resistance on trichothecene production and aggressiveness of Fusarium graminearum. Mol. Plant Microbe Interact. 2009, 22, 1143-1150. [CrossRef]

18. Qiu, J.; Shi, J. Genetic relationships, carbendazim sensitivity and mycotoxin production of the Fusarium graminearum populations from maize, wheat and rice in eastern China. Toxins 2014, 6, 2291-2309. [CrossRef]

19. Chen, C.J.; Wang, J.X.; Luo, Q.Q.; Yuan, S.K.; Zhou, M.G. Characterization and fitness of carbendazim-resistant strains of Fusarium graminearum (wheat scab). Pest. Manag. Sci. 2007, 63, 1201-1207. [CrossRef]

20. Chen, Y.; Chen, C.; Wang, J.; Jin, L.; Zhou, M. Genetic study on JS399-19 resistance in hyphal fusion of Fusarium graminearum by using nitrate nonutilizing mutants as genetic markers. J. Genet. Genom. 2007, 34, 469-476. [CrossRef]

21. Mikaberidze, A.; Paveley, N.; Bonhoeffer, S.; van den Bosch, F. Emergence of resistance to fungicides: The role of fungicide dose. Phytopathology 2017, 107, 545-560. [CrossRef] [PubMed]

22. Al-Hatmi, A.M.; Meis, J.F.; de Hoog, G.S. Fusarium: Molecular diversity and intrinsic drug resistance. PLoS Pathog. 2016, 12, e1005464. [CrossRef] [PubMed]

23. Cordova-Alcantara, I.M.; Venegas-Cortes, D.L.; Martinez-Rivera, M.A.; Perez, N.O.; Rodriguez-Tovar, A.V. Biofilm characterization of Fusarium solani keratitis isolate: Increased resistance to antifungals and UV light. J. Microbiol. 2019, 57, 485-497. [CrossRef] [PubMed]

24. Muregi, F.W. Antimalarial drugs and their useful therapeutic lives: Rational drug design lessons from pleiotropic action of quinolines and artemisinins. Curr. Drug Discov. Technol. 2010, 7, 280-316. [CrossRef] [PubMed]

25. Deising, H.B.; Reimann, S.; Pascholati, S.F. Mechanisms and significance of fungicide resistance. Braz. J. Microbiol. 2008, 39, 286-295. [CrossRef] [PubMed]

26. Al-Bakri, A.G.; Othman, G.; Bustanji, Y. The assessment of the antibacterial and antifungal activities of aspirin, EDTA and aspirin-EDTA combination and their effectiveness as antibiofilm agents. J. Appl. Microbiol. 2009, 107, 280-286. [CrossRef]

27. Taha, M.O.; Al-Bakri, A.G.; Zalloum, W.A. Discovery of potent inhibitors of pseudomonal quorum sensing via pharmacophore modeling and in silico screening. ACS Med. Chem. Lett. 2006, 16, 5902-5906. [CrossRef]

28. Cikes, M.; Vranjesevic, B.; Tomic, M.; Jamnicky, O. A successful treatment of formation damage caused by high-density brine. Spe. Prod. Eng. 1990, 5, 175-179. [CrossRef]

29. Crabtree, M.; Eslinger, D.; Fletcher, P.; Miller, M.; King, G. Fighting scale-removal and prevention. Oilfield Rev. $1999,11,30-45$.

30. Banin, E.; Brady, K.M.; Greenberg, E.P. Chelator-induced dispersal and killing of Pseudomonas aeruginosa cells in a biofilm. Appl. Environ. Microbiol. 2006, 72, 2064-2069. [CrossRef]

31. Gil, M.L.; Casanova, M.; Martinez, J.P. Changes in the cell wall glycoprotein composition of Candida albicans associated to the inhibition of germ tube formation by EDTA. Arch. Microbiol. 1994, 161, 489-494. [CrossRef] [PubMed]

32. Gray, G.W.; Wilkinson, S.G. The effect of ethylenediaminetetra-acetic acid on the cell walls of some gram-negative bacteria. J. Gen. Microbiol. 1965, 39, 385-399. [CrossRef] [PubMed]

33. Ramage, G.; Wickes, B.L.; López-Ribot, J.L. Inhibition on Candida albicans biofilm formation using divalent cation chelators (EDTA). Mycopathologia 2007, 164, 301-306. [CrossRef] [PubMed]

34. Saadat, M.; Roudbarmohammadi, S.; Yadegari, M.; Khavarinejad, R. Evaluation of antibacterial effects of catechin and EDTA on planktonic and biofilm cells of Pseudomonas aeruginosa. Malays. J. Microbiol. 2013, 9, 184-188. [CrossRef]

35. Yakandawala, N.; Gawande, P.V.; LoVetri, K.; Madhyastha, S. Effect of ovotransferrin, protamine sulfate and EDTA combination on biofilm formation by catheter-associated bacteria. J. Appl. Microbiol. 2010, 102, 722-727. [CrossRef] 
36. Chauhan, A.A. Full and broad-spectrum in vivo eradication of catheter-associated biofilms using gentamicin-EDTA antibiotic lock therapy. Antimicrob. Agents Chemother. 2012, 56, 6310-6318. [CrossRef]

37. Shaikh, A.I.; Musaddiq, M. Antibiotic-EDTA combination induced dispersal of Pseudomonas aeruginosa biofilm. J. Pure Appl. Microbiol. 2012, 6, 363-367.

38. Bartnicki-Garcia, S. Cell wall chemistry, morphogenesis, and taxonomy of fungi. Annu. Rev. Microbiol. 1968, 22, 87-108. [CrossRef]

39. Brent, K.J. Fungicide Resistance in Crop Pathogens: How Can It Be Managed? 2nd ed.; Fungicide Resistance Action Committee: Basel, Switzerland, 1995; Available online: http:/ / www.frac.info (accessed on 27 December 2020).

40. Dekker, J. Prospects for the use of systemic fungicides in view of the resistance problem. Lab. Phytopathol. 1976, 3, 60-66.

41. Grimmer, M.K.; van den Bosch, F.; Powers, S.J.; Paveley, N.D. Evaluation of a matrix to calculate fungicide resistance risk. Pest Manag. Sci. 2014, 70, 1008-1016. [CrossRef] [PubMed]

42. van den Bosch, F.; Gilligan, C.A. Models of fungicide resistance dynamics. Annu. Rev. Phytopathol. 2008, 46, 123-147. [CrossRef] [PubMed]

43. Ates, M.; Akdeniz, B.G.; Sen, B.H. The effect of calcium chelating or binding agents on Candida albicans. Oral Surg. Oral. Med. Oral. Pathol. Oral. Radiol. Endod. 2005, 100, 626-630. [CrossRef] [PubMed]

44. Ding, Q.; Alborzi, S.; Bastarrachea, L.J.; Tikekar, R.V. Novel sanitization approach based on synergistic action of UV-A light and benzoic acid: Inactivation mechanism and a potential application in washing fresh produce. Food Microbiol. 2018, 72, 39-54. [CrossRef] [PubMed]

45. Lai, Y.-W.; Campbell, L.T.; Wilkins, M.R.; Pang, C.N.I.; Chen, S.; Carter, D.A. Synergy and antagonism between iron chelators and antifungal drugs in Cryptococcus. Int. J. Antimicrob. Agents 2016, 48, 388-394. [CrossRef] [PubMed]

46. Mesterhazy, A.; Toth, B.; Varga, M.; Bartok, T.; Szabo-Hever, A.; Farady, L.; Lehoczki-Krsjak, S. Role of fungicides, application of nozzle types, and the resistance level of wheat varieties in the control of Fusarium head blight and deoxynivalenol. Toxins 2011, 3, 1453-1483. [CrossRef]

47. Latge, J.P. The cell wall: A carbohydrate armour for the fungal cell. Mol. Microbiol. 2007, 66, 279-290. [CrossRef]

48. Holmes, A.R.; Cannon, R.D.; Shepherd, M.G. Effect of calcium ion uptake on Candida albicans morphology. FEMS Microbiol. Lett. 2010, 77, 187-194. [CrossRef]

49. Robertson, E.J.; Wolf, J.M.; Casadevall, A. EDTA inhibits biofilm formation, extracellular vesicular secretion, and shedding of the capsular polysaccharide glucuronoxylomannan by Cryptococcus neoformans. Appl. Environ. Microbiol. 2012, 78, 7977-7984. [CrossRef]

50. Choi, W.J.; Cabib, E. The use of divalent cations and $\mathrm{pH}$ for the determination of specific yeast chitin synthetases. Anal. Biochem. 1994, 219, 368. [CrossRef]

51. Choi, W.J.; Sburlati, A.; Cabib, E. Chitin synthase 3 from yeast has zymogenic properties that depend on both the CAL1 and the CAL3 genes. Proc. Natl. Acad. Sci. USA 1994, 91, 4727-4730. [CrossRef] [PubMed]

52. Cheng, W.; Song, X.S.; Li, H.P.; Cao, L.H.; Sun, K.; Qiu, X.L.; Xu, Y.B.; Yang, P.; Huang, T.; Zhang, J.B.; et al. Host-induced gene silencing of an essential chitin synthase gene confers durable resistance to Fusarium head blight and seedling blight in wheat. Plant Biotechnol. J. 2015, 13, 1335-1345. [CrossRef] [PubMed]

53. Orlean, P. Two chitin synthases in Saccharomyces cerevisiae. J. Biol. Chem. 1987, 262, 5732-5739. [PubMed]

54. Kim, S.W.; Park, J.K.; Lee, C.H.; Hahn, B.S.; Koo, J.C. Comparison of the antimicrobial properties of chitosan oligosaccharides (COS) and EDTA against Fusarium fujikuroi causing rice bakanae disease. Curr. Microbiol. 2016, 72, 496-502. [CrossRef]

55. Chen, Y.; Zhou, M.G. Characterization of Fusarium graminearum isolates resistant to both carbendazim and a new fungicide JS399-19. Phytopathology 2009, 99, 441-446. [CrossRef]

56. Duvick, J.P.; Rood, T.; Rao, A.G.; Marshak, D.R. Purification and characterization of a novel antimicrobial peptide from maize (Zea mays L.) kernels. J. Biol. Chem. 1992, 267, 18814-18820.

57. Song, X.S.; Li, H.P.; Zhang, J.B.; Song, B.; Huang, T.; Du, X.M.; Gong, A.D.; Liu, Y.K.; Feng, Y.N.; Agboola, R.S.; et al. Trehalose 6-phosphate phosphatase is required for development, virulence and mycotoxin biosynthesis apart from trehalose biosynthesis in Fusarium graminearum. Fungal. Genet. Biol. 2014, 63, 24-41. [CrossRef]

58. Audenaert, K.; Callewaert, E.; Hofte, M.; De Saeger, S.; Haesaert, G. Hydrogen peroxide induced by the fungicide prothioconazole triggers deoxynivalenol (DON) production by Fusarium graminearum. BMC Microbiol. 2010, 10, 112. [CrossRef]

59. Zhou, Z.; Duan, Y.; Zhou, M. Carbendazim-resistance associated $\beta_{2}$-tubulin substitutions increase deoxynivalenol biosynthesis by reducing the interaction between $\beta_{2}$-tubulin and IDH3 in Fusarium graminearum. Environ. Microbiol. 2020, 22, 598-614. [CrossRef]

60. Xu, C.; Hou, Y.; Wang, J.; Yang, G.; Liang, X.; Zhou, M. Activity of a novel strobilurin fungicide benzothiostrobin against Sclerotinia sclerotiorum. Pestic Biochem. Physiol. 2014, 115, 32-38. [CrossRef]

61. Valentin, J.L.; Watling, R.J. Provenance establishment of coffee using solution ICP-MS and ICP-AES. Food Chem. 2013, 141, 98-104. [CrossRef] [PubMed] 